\title{
Circadian control of isoprene emissions from oil palm (Elaeis guineensis)
}

\section{Running title: Circadian control of isoprene emissions from oil palm}

Michael J. Wilkinson ${ }^{\dagger}$, Susan M. Owen ${ }^{\dagger}$, Malcolm Possell ${ }^{\dagger}$, James Hartwell*, Peter

Gould $^{*}$, Anthony Hall ${ }^{*}$, Claudia Vickers ${ }^{\S} \&$ C. Nicholas Hewitt ${ }^{\dagger+}$

${ }^{\dagger}$ Department of Environmental Science, Lancaster Environment Centre, Lancaster University, Lancaster LAI 4YQ, UK

* School of Biological Sciences, University of Liverpool, Liverpool L69 7ZB, UK

${ }^{\S}$ Department of Biological Sciences, University of Essex, Colchester CO4 3SQ, UK

${ }^{+}$Corresponding author, email n.hewitt@lancaster.ac.uk, phone +44 1524 593931, fax +441524593985

\section{Author email addresses:}

M.J.Wilkinson,m.j.wilkinson@lancaster.ac.uk

Susan M. Owen, sue.owen@creaf.uab.es

Malcolm Possell,m.possell@lancaster.ac.uk

James Hartwell, James.Hartwell@liverpool.ac.uk

Peter Gould, p.d.gould@liverpool.ac.uk

Claudia Vickers, cvickers@essex.ac.uk

AnthonyHall, anthony.hall@liverpool.ac.uk

Footnote: S.M. Owen currently employed at Centre de Recerca Ecològica i Aplicacions Forestals (CREAF). Universitat Autònoma de Barcelona, 08193. Bellaterra. Spain. 


\section{Word count}

Total count excluding figure legends and tables: 6339

Number of words in summary: 175

Number of words in introduction: $\mathbf{8 6 1}$

Number of words in results section: 1551

Number of words in discussion: 918

Number of words in experimental procedures: 1130

Number of words in reference list: 1704

Figures: 5

Tables: 1

Total number of pages: $\mathbf{3 4}$ 


\section{Summary}

The emission of isoprene from the biosphere to the atmosphere has a profound effect on the Earth's atmospheric system. Until now, it has been assumed that the primary short-term controls on isoprene emission are photosynthetically active radiation and temperature. Here we show for the first time that isoprene emissions from a tropical tree (oil palm, Elaeis guineensis) are under strong circadian control and that the circadian clock is potentially able to gate light induced isoprene emissions. These rhythms are robustly temperature compensated with isoprene emissions still under circadian control at $38^{\circ} \mathrm{C}$. This is well beyond the acknowledged temperature range of all previously described circadian phenomena in plants. Furthermore, rhythmic expression of $L H Y / C C A 1$, a genetic component of the central clock in Arabidopsis thaliana, is still maintained at these elevated temperatures in oil palm. Maintenance of the CCA1/LHY-TOC1 molecular oscillator at these temperatures in oil palm allows for the possibility that this system is involved in the control of isoprene emission rhythms. This study contradicts the accepted theory that isoprene emissions are primarily light induced.

Keywords: Isoprene, oil palm, diurnal variability, circadian clock, circadian gating.

Abbreviations: $I E$ (isoprene emission rate); $I E_{1000 / 30}$ (isoprene emission rate at PAR of $1000 \mu \mathrm{mol} \mathrm{m} \mathrm{m}^{-2}$ and $30^{\circ} \mathrm{C}$ leaf temperature); LL (constant light). 


\section{$\underline{\text { Introduction }}$}

Emissions of the volatile organic compound isoprene (2-methyl-1,3-butadiene;

$\mathrm{C}_{5} \mathrm{H}_{8}$ ) from the biosphere affect the oxidative capacity of the atmosphere (Shallcross and Monks, 2000) and hence have the potential to modify regional ozone pollution (Pierce et al., 1998), lead to secondary aerosol formation (Claeys et al., 2004) and indirectly control the lifetime of the greenhouse gas methane (Poisson et al., 2000). Isoprene is synthesized in the chloroplast, mainly from recently assimilated carbon (Karl et al., 2002), and although synthesis is loosely coupled to photosynthetic processes through substrate availability and requirements for adenosine triphosphate, its emission may become uncoupled from photosynthesis, particularly at elevated temperatures (Harley et al., 1999). On time scales of minutes to hours, the primary controls that are known to affect isoprene emission rate $(I E)$ are photosynthetically active radiation (PAR) and leaf temperature (Harley et al., 1999), which regulate substrate availability and enzyme kinetics (Sharkey et al., 2001). Isoprene is emitted through stomata but changes in stomatal aperture have negligible effects on its emission due to its high volatility and low solubility in water (Niinemets and Reichstein, 2003a). In the longer term, carbon dioxide concentration (Possell et al., 2004; Possell et al., 2005), leaf phenology (Kuzma and Fall, 1993), leaf nitrogen content (Harley et al., 1994; Rosenstiel et al., 2004), and environmental stresses such as soil water potential (Pegoraro et al., 2004) and herbivory (Funk et al., 1999) also affect the magnitude of IE.

To compile emission inventories for this important compound, branch and leaf enclosure techniques are commonly employed to determine the isoprene emission rate for individual plant species at $1000 \mu \mathrm{mol} \mathrm{m}^{-2} \mathrm{~s}^{-1}$ (PAR) and $30^{\circ} \mathrm{C}$ leaf temperature. Here we define this parameter as $I E_{1000 / 30}$. An estimate of $I E$ at ambient PAR and 
temperature throughout the day for each species is obtained by scaling $I E_{1000 / 30}$ using light and temperature correction factors (Guenther et al., 1995). Species composition and density are then used to estimate a regional average emission flux. However, there is high variability in $I E_{1000 / 30}$ measurements with considerable day to day, seasonal and inter- and intra-species variability (e.g. http://www.acd.ucar.edu:8080/voc/vocIndex.jsp; http://www.es.lancs.ac.uk/cnhgroup/iso-emissions.pdf.). Significant diurnal variability in the magnitude of $I E_{1000 / 30}$ for several tree species has also been reported. Isoprene emission rates from cottonwood and oak, standardized to $I E_{1000 / 30}$, were observed to be significantly higher in the afternoon than in the morning (Funk et al., 2003). Yet in the same study no variability in $I E_{1000 / 30}$ for eucalyptus was observed. In other studies, $I E_{1000 / 30}$ for oak has been shown to increase over a day by as much as $50 \%$; this increase could be predicted using changes in weather conditions over the previous 24 hours (Sharkey et al., 1999; Geron et al., 2000). However, some of the variability in $I E_{1000 / 30}$ cannot be explained by present understanding of the effects of short-term environmental and biological controls on isoprene synthesis. As well as changes in $I E_{1000 / 30}$ over the course of a day, significant changes in the concentration of the isoprene precursor, dimethylallyl diphosphate (DMAPP), have been observed (Geron $e t$ al., 2000; Wolfertz et al., 2003; Rosenstiel et al., 2004) but without a link being made to possible circadian control.

A wide range of fundamental processes in plant biology are optimized and coordinated each day due to regulation by an endogenous circadian clock. Examples include leaf movements, hypocotyl elongation, gene transcript and protein abundance rhythms and the photoperiodic control of flowering time (McClung, 2001). A number of the genes that constitute the molecular components of the positive-negative 
autoregulatory feedback loops that comprise the plant circadian clock have been identified in Arabidopsis thaliana. CIRCADIAN CLOCK ASSOCIATED1 (CCA1) and LATE ELONGATED HYPOCOTYL (LHY) and the pseudo-response regulator/CONSTANS-domain protein TIMING OF CAB EXPRESSION1 (TOC1) form at least one of the interlocking loops at the core of the plant clock (Alabadi et al., 2001). $C C A l$ and $L H Y$ transcript abundance is under circadian control and peaks at dawn (Schaffer et al., 1998; Wang and Tobin, 1998). Orthologous clock genes have been characterised in plant species as diverse as rice (Izawa et al., 2003), common ice plant (Mesembryanthemum crystallinum) (Boxall et al., 2005), beans (Phaseolus vulgaris) (Kaldis et al., 2003) and chestnut (Castanea sativa) (Ramos et al., 2005) suggesting that the genetic components of the clock are broadly conserved in higher plants. In Arabidopsis, all known clock-controlled processes have been shown to be ultimately responding to the central $C C A 1 / L H Y-T O C 1$ oscillator including gas exchange, leaf movements, gene expression rhythms and flowering time (Dodd et al., 2005). The CCA1 and LHY proteins belong to the Myb family of transcription factors (Schaffer $e t$ al., 1998; Wang and Tobin, 1998) and thus act at the transcriptional level to control gene expression.

Here we report that isoprene emission from the fronds of oil palm trees are under the control of a circadian clock. Circadian rhythms of isoprene emission persist for several days at constant light and temperature, are robust and temperature compensated between $25^{\circ} \mathrm{C}$ and $38^{\circ} \mathrm{C}$ and are gated in a circadian fashion. Using an oil palm $C C A 1 / L H Y$ orthologue as a marker, we establish that the molecular clock also operates in oil palm trees up to $38^{\circ} \mathrm{C}$ and thus that this clock is potentially capable of coordinating isoprene emission rhythms. 


\section{$\underline{\text { Results }}$}

\section{Isoprene emission in oil palm is under circadian control}

As noted above, diurnal variability in $I E$ standardised to $I E_{1000 / 30}$ has been observed previously (Sharkey et al., 1999; Geron et al., 2000; Funk et al., 2003). We have confirmed this using field measurements of $I E_{1000 / 30}$ from oil palm growing on a plantation in Malaysia, which showed a strong diurnal trend (Fig 1a). This trend was also observed in laboratory grown plants under controlled conditions (Figure 1b). To determine whether this short-term variability in $I E_{1000 / 30}$ is caused by circadian regulation, we monitored $I E_{1000 / 30}$ from a frondlet under constant illumination (LL) for $70 \mathrm{~h}$ at $1000 \mu \mathrm{mol} \mathrm{m} \mathrm{s}^{-2}$ and constant $30{ }^{\circ} \mathrm{C}$ leaf temperature. If isoprene synthesis is under circadian control, we would expect to observe free running rhythms in $I E_{1000 / 30}$ over a period of several days. The frondlet was illuminated from dark at 06:00 (normal 'lights on'). $I E_{1000 / 30}$ increased for $4 \mathrm{~h}$, reaching a maximum $\left(I E_{\max }\right)$ of $\sim 40 \mathrm{nmol} \mathrm{C} \mathrm{m}{ }^{-2}$ $\mathrm{s}^{-1}$, before declining over the rest of the day (Figure $2 \mathrm{a}$ ). $I E_{1000 / 30}$ fell during subjective night (i.e. when the frondlet is not normally illuminated) to approximately $10 \%$ of $I E_{\max }$ before rising again the following subjective morning. Over the following $48 \mathrm{~h}$, oscillations in $I E_{1000 / 30}$ continued but with a dampening of $I E_{\max }$. The period of oscillation in this free running cycle was $23.1 \mathrm{~h}$. The persistence of rhythms in the absence of a dark-light cycle or other exogenous signals clearly indicates that isoprene synthesis is regulated by an internal biological clock.

To investigate the effect of different leaf temperatures on these free running rhythms in $I E$, we repeated the experiment at leaf temperatures of $25^{\circ} \mathrm{C}\left(I E_{1000 / 25}\right)$ and $38^{\circ} \mathrm{C}\left(I E_{1000 / 38}\right)$ (Figure $2 \mathrm{~b}$ and $2 \mathrm{c}$ respectively). At these temperatures, isoprene 
emissions oscillated over several days with the magnitude and amplitude of the oscillations dependent on leaf temperature and correlated positively with these parameters. The increase in absolute emission rates with increasing temperature is consistent with present understanding of the effects of temperature on isoprene synthase activity (Sharkey et al., 2001). As well as $I E$ increasing with temperature, Figures 2a-c show that the oscillations in $I E$ become more robust at elevated temperatures when the central components of the plant circadian clock are believed to become arrhythmic. The period of the $I E$ rhythm was $25.5 \mathrm{~h}$ at $25^{\circ} \mathrm{C}$ and $21.4 \mathrm{~h}$ at $38^{\circ} \mathrm{C}$, revealing that the rhythm shows significant temperature compensation. The robust circadian rhythm in $I E$ at all three temperatures is not reflected in assimilation rates (A); no circadian rhythm in A was observed (Figure 2d-f). This suggests a total uncoupling of $I E$ from photosynthesis. Rhythmicity was observed in stomatal conductance ( $\left.g_{s}\right)$ (Fig 2d-f) but the period length differed to that of $I E$ such that the two parameters were not in phase with one another (see Table 1). These results confirm previous findings which have shown that $I E$ is independent of $\mathrm{g}_{\mathrm{s}}$ (Fall, 1999; Niinemets and Reichstein, 2003a; 2003b).

Table 1. Length of period in $I E$ and $g_{s}$ at varying temperatures

\begin{tabular}{ccc}
\hline $\begin{array}{c}\text { Leaf temperature } \\
\left({ }^{\circ} \mathrm{C}\right)\end{array}$ & $I E$ period $(\mathrm{h})$ & $\mathrm{g}_{\text {s }}$ period $(\mathrm{h})$ \\
\hline 25 & 25.5 & 21.2 \\
30 & 23.1 & 26.7 \\
38 & 21.4 & 22.1 \\
\hline
\end{tabular}




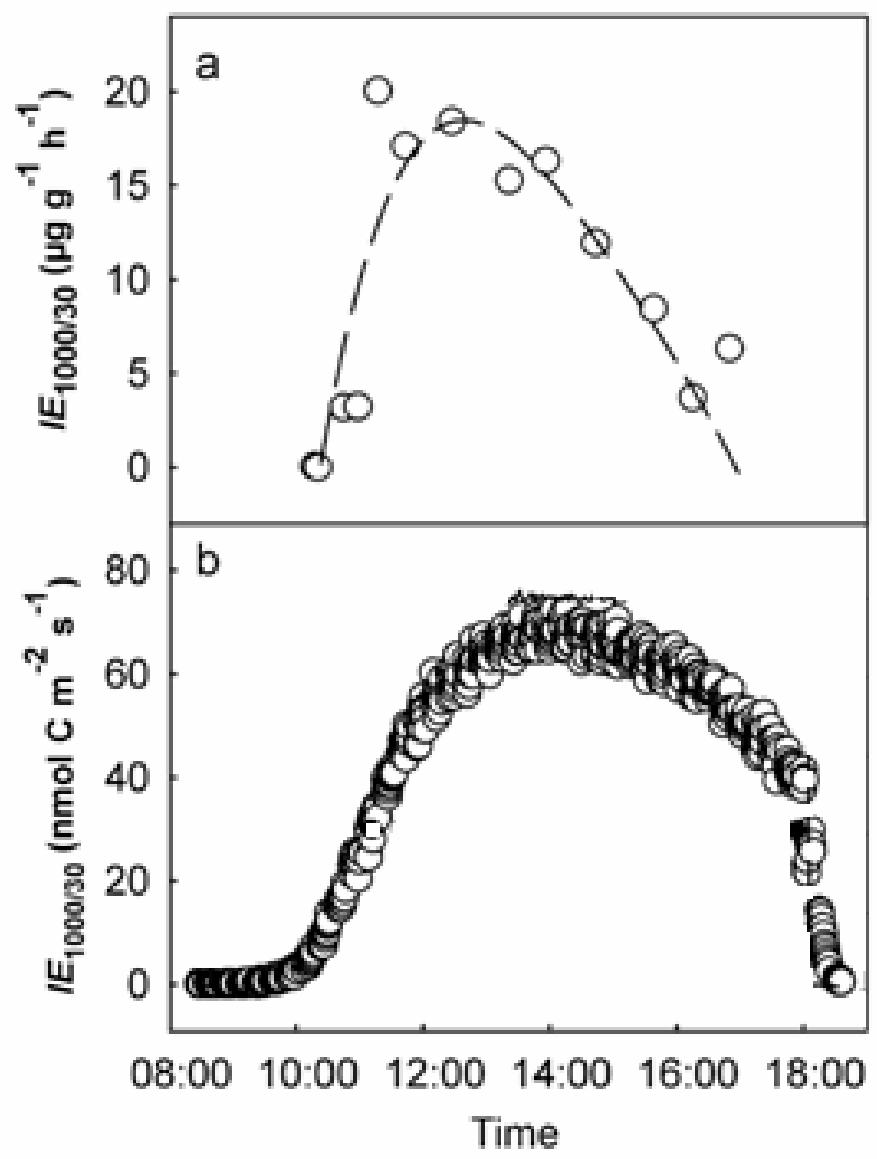

Figure 1. Variability in isoprene $I E$ at $1000 \mu \mathrm{mol} \mathrm{m} \mathrm{m}^{-2} \mathrm{~s}^{-1}$ and $30^{\circ} \mathrm{C}$ leaf temperature $\left(I E_{1000 / 30}\right)$. (a) Field measurements of $I E_{1000 / 30}$ from oil palm taken in an oil palm plantation in Sabah, Malaysia. PAR and temperature were held constant at $1000 \mu \mathrm{mol}$ $\mathrm{m}^{-2} \mathrm{~s}^{-1}$ and $30^{\circ} \mathrm{C}$ from 10:00 to $16: 00$ hours. (b) $I E_{1000 / 30}$ measured in the laboratory. PAR and temperature were held constant at $1000 \mu \mathrm{mol} \mathrm{m} \mathrm{m}^{-2} \mathrm{~s}^{-1}$ and $30^{\circ} \mathrm{C}$ from 10:00 to 18:00 hours. 
To eliminate the possibility of cross-talk signalling between neighbouring cells outside the gas exchange cuvette, which were at a different temperature to the measured cells inside the cuvette, whole frond measurements of $I E$ were made using excised fronds, with the whole frond kept at a constant temperature. Isoprene emissions from these fronds were measured at leaf temperatures of 25 and $38^{\circ} \mathrm{C}$ at light intensity of 120 $\mu \mathrm{mol} \mathrm{m} \mathrm{s}^{-2}\left(I E_{120 / 25}\right.$ and $I E_{120 / 38}$; Figures $2 \mathrm{~g}$ and h respectively). At $25^{\circ} \mathrm{C}$ (Figure $2 \mathrm{~g}$ ), whole frond isoprene $I E_{120 / 25}$ oscillated with a similar period to that seen in the leaf cuvette (Figure $2 \mathrm{~b}$ ). At $38^{\circ} \mathrm{C}$ (Figure $2 \mathrm{~h}$ ), the periodicity in $I E_{120 / 38}$ was seen for $48 \mathrm{~h}$, after which wilting of the excised frond occurred and $I E$ became arrhythmic. From these whole frond measurements at both $25^{\circ} \mathrm{C}$ and $38^{\circ} \mathrm{C}$ we conclude that no cross-talk signalling occurred between neighbouring cells during the cuvette experiments. 


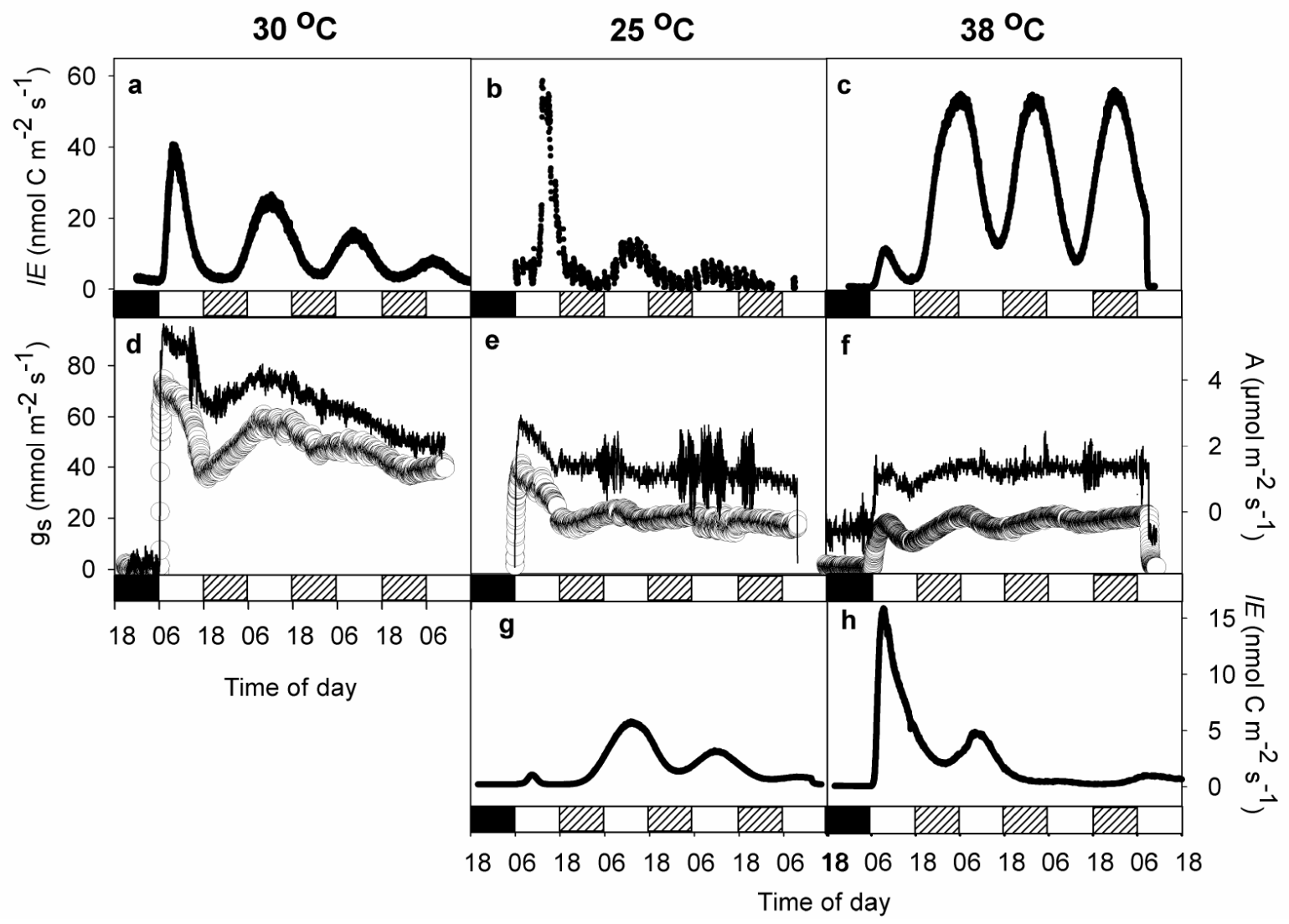

Figure 2. Leaf level free running isoprene emission rates $(I E)(\mathrm{a}-\mathrm{c})$ and assimilation rates (A) (top trace) and stomatal conductance $\left(\mathrm{g}_{\mathrm{s}}\right)$ (bottom trace) (d-f) from oil palm measured in LL (constant light; $\left.1000 \mu \mathrm{mol} \mathrm{m} \mathrm{s}^{-1}\right)$ for $70 \mathrm{~h}$ at $30^{\circ} \mathrm{C}(\mathrm{a}+\mathrm{d}), 25^{\circ} \mathrm{C}(\mathrm{b}+$ e) and $38^{\circ} \mathrm{C}(\mathrm{c}+\mathrm{f})$ leaf temperature. Full frond $I E$ measured in LL $\left(120 \mu \mathrm{mol} \mathrm{m}^{-2} \mathrm{~s}^{-1}\right)$ at $25^{\circ} \mathrm{C}$ and $38{ }^{\circ} \mathrm{C}$ are also shown in (g) and (h) respectively. Note: in panel b, $I E$ values have been multiplied by 10 . 


\section{The oil palm molecular clock maintains function at high temperatures}

The robust circadian rhythm of isoprene emissions at $38^{\circ} \mathrm{C}$ (Figs. $2 \mathrm{c}$ and $2 \mathrm{~h}$ ) indicate that a circadian clock must be operating in oil palm at a significantly higher temperature than any previously recorded plant circadian rhythm. For example, the circadian rhythm of $\mathrm{CO}_{2}$ fixation in the tropical CAM species Kalanchö̈ daigremontiana becomes arrhythmic above $32{ }^{\circ} \mathrm{C}$, even in plants that were pre-adapted to a daytime temperature of $34{ }^{\circ} \mathrm{C}$ for one month prior to analysis (Grams et al., 1995). It was therefore important to examine the operation of the molecular clock in oil palm at $38{ }^{\circ} \mathrm{C}$ to determine whether the molecular oscillator was operating and, therefore, capable of controlling the observed $I E$ rhythm. We identified an oil palm expressed sequence tag (EST), which we called $E g C C A 1 / L H Y$, which is an orthologue of the Arabidopsis central clock components $C C A 1$ and $L H Y$ (see Materials and Methods). We collected frondlet samples every six hours from excised oil palm fronds maintained in LL at both $25^{\circ} \mathrm{C}$ and $38^{\circ} \mathrm{C}$ using a whole-frond chamber. We isolated RNA from each frondlet sample and used a real time-polymerase chain reaction (RT-PCR) technique to examine changes in the steady-state transcript abundance of $E g C C A 1 / L H Y$ (Fig. 3). This analysis revealed robust rhythms in $\mathrm{EgCCA1/LHY}$ transcript abundance at both $25^{\circ} \mathrm{C}$ and $38{ }^{\circ} \mathrm{C}$, supporting the hypothesis that $I E$ could be controlled by the $C C A 1 / L H Y$ TOC1 central molecular clock. It is noteworthy that the period of the $E g C C A 1 / L H Y$ rhythm at $38{ }^{\circ} \mathrm{C}$ is significantly shorter than the rhythm at $25{ }^{\circ} \mathrm{C}$ (Fig. 3); this correlates well with the shortening of the period of the $I E$ rhythm at $38{ }^{\circ} \mathrm{C}$ relative to $25{ }^{\circ} \mathrm{C}$ (Figs $2 \mathrm{a}-\mathrm{c})$. 


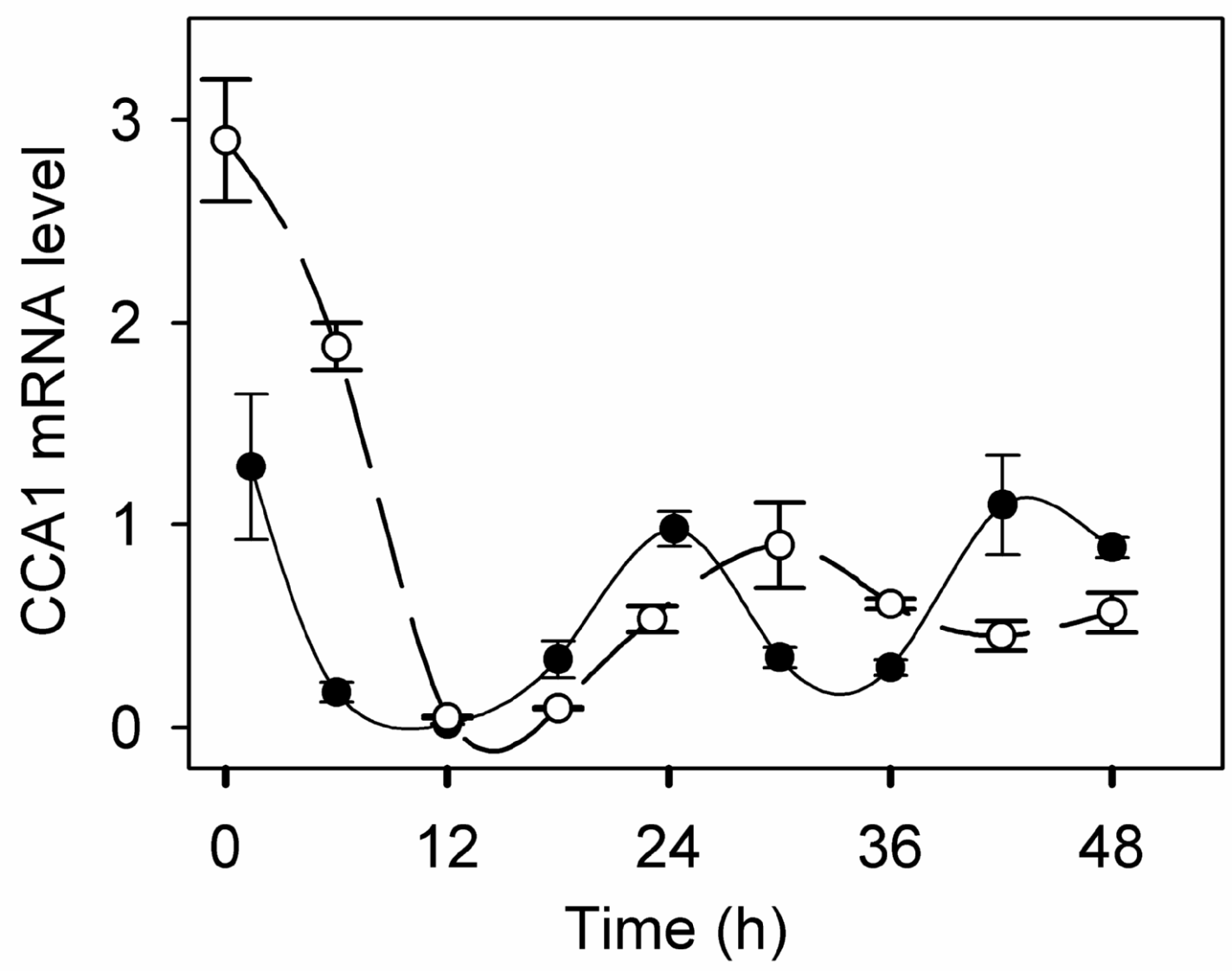

Figure 3. Steady state changes in mRNA transcript abundance of $E g C C A 1 / L H Y$ at leaf temperatures of $25{ }^{\circ} \mathrm{C}$ (open circles) and $38{ }^{\circ} \mathrm{C}$ (closed circles) under constant illumination. 


\section{Isoprene emissions are circadian-gated}

Circadian clock outputs are often gated such that they can only be activated at a specific phase in the $24 \mathrm{~h}$ cycle. For example, the circadian rhythm of nocturnal $\mathrm{CO}_{2}$ fixation in the Crassulacean acid metabolism species Kalanchoë fedtschenkoi is gated in response to temperature (Hartwell et al., 2002). When the temperature was reduced from the non-permissive $30{ }^{\circ} \mathrm{C}$ to the permissive $15{ }^{\circ} \mathrm{C}$ during the subjective light period, no $\mathrm{CO}_{2}$ fixation was observed in this species, but when the temperature was reduced to $15{ }^{\circ} \mathrm{C}$ during the subjective dark period, $\mathrm{CO}_{2}$ fixation was initiated. $I E$ has previously been assumed to respond directly to light, with zero emission in the dark, i.e. emissions will only occur if the frondlet is illuminated. However, if the induction of isoprene is gated by the circadian clock, we would predict that emissions should only occur when a frondlet is illuminated during the subjective light period. Illumination of a frondlet at the beginning of the subjective dark period should not give rise to isoprene emissions until the subsequent subjective light period.

We investigated this by keeping two leaves in the dark at the end of subjective day; one for $24 \mathrm{~h}$, the other for $36 \mathrm{~h}$. The frondlet kept in the dark for $24 \mathrm{~h}$ was illuminated with $1000 \mu \mathrm{mol} \mathrm{m} \mathrm{m}^{-2}$ at 18:00, at the onset of subjective dark, at a constant leaf temperature of $30{ }^{\circ} \mathrm{C}$. Following illumination, $I E_{1000 / 30}$ was essentially zero until the start of the next subjective day, at which time it increased significantly (Figure 4: black line). This demonstrates an uncoupling of $I E$ from the light stimulus, and is in contrast to all previous assumptions about the light dependency of $I E$. Continued illumination of the frondlet, for a further $24 \mathrm{~h}$, resulted in diurnal oscillations in $I E_{1000 / 30}$ with a period $\sim 24 \mathrm{~h}$. During the second subjective night, $I E_{1000 / 30}$ did not fall to zero but decreased to approximately $20 \%$ of the preceding $I E_{\max }$ before increasing during the 
following subjective day. The frondlet that was kept in the dark for $36 \mathrm{~h}$ (Figure 4: open circles) was illuminated at the start of subjective day. $I E_{1000 / 30}$ was zero for the first hour after the frondlet was illuminated and then increased significantly, reaching $I E_{\max }$ at 09:40 before starting to decline. This circadian gating of isoprene emission is similar to the gating described for the acute induction of the chlorophyll $\mathrm{A} / \mathrm{B}$ binding protein (CAB) by light in Arabidopsis thaliana (Millar and Kay, 1996). Figure 4 also shows that the time of day that $I E_{\max }$ was achieved for the frondlet illuminated at 18:00 (black line) was delayed by $9 \mathrm{~h}$ when compared to the frondlet illuminated at 06:00 (open circles). This suggests there was a shift in phase of the circadian rhythm due to the frondlet being illuminated at the beginning of a subjective dark period, i.e. $12 \mathrm{~h}$ out of phase with the prior light entrainment of the frondlet. These results demonstrate that the isoprene emissions are circadian-gated. 


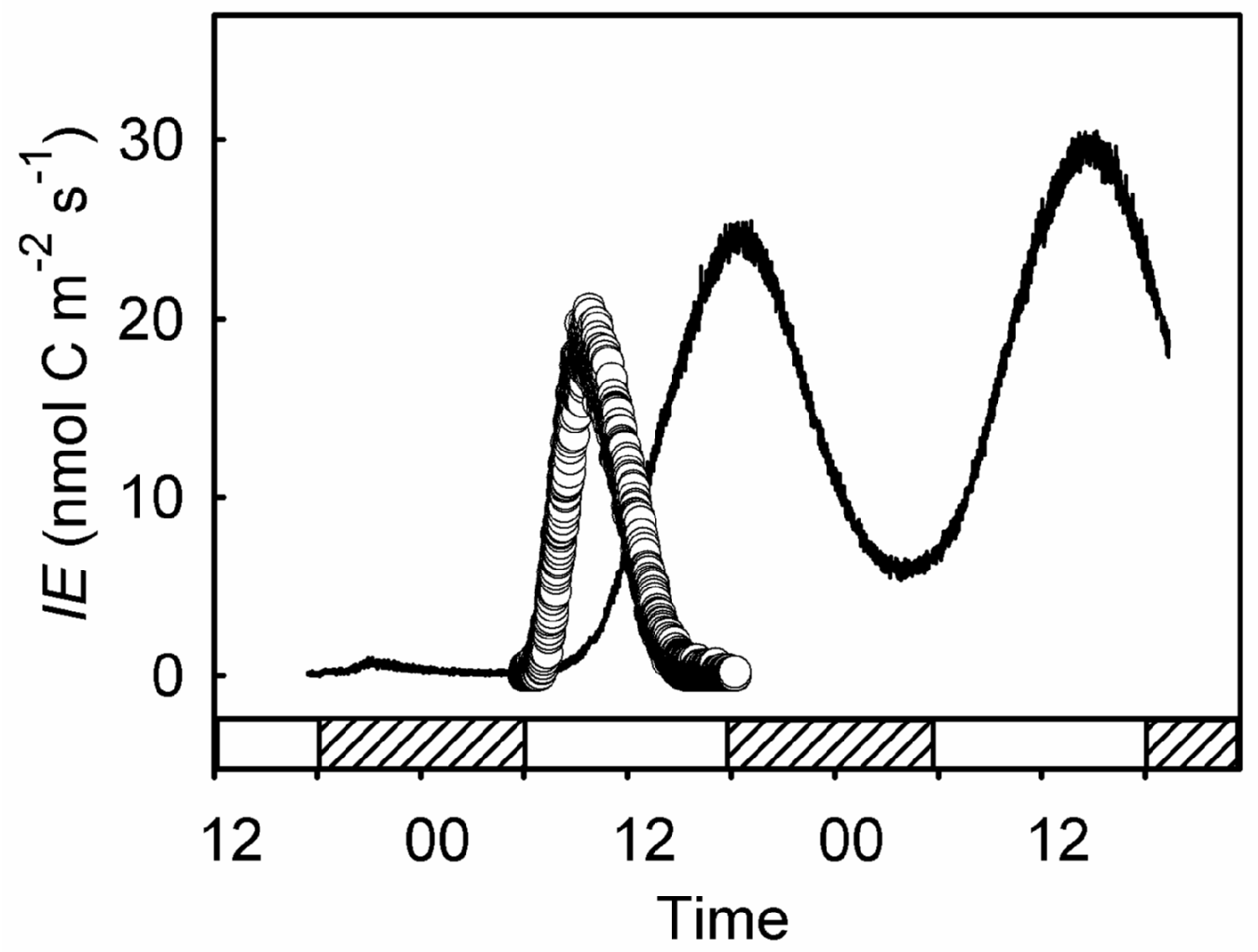

Figure 4. Circadian gating of isoprene emission rates from oil palm at $1000 \mu \mathrm{mol} \mathrm{m}^{-2} \mathrm{~s}^{-}$ ${ }^{1}$ and $30{ }^{\circ} \mathrm{C}$. Note that when a frondlet was kept in the dark for $24 \mathrm{~h}$ and illuminated at the start of subjective day, initiation of $I E$ was delayed by $12 \mathrm{~h}$ (black line). When a frondlet kept in the dark for $36 \mathrm{~h}$ was illuminated at the start of subjective day (open circles) no delay in the onset of isoprene emission was observed. Comparison of emission rates between the two leaves shows that illuminating the frondlet at the start of subjective night resulted in a shift of phase of $\sim 9 \mathrm{~h}$. 


\section{Diurnal variability in $I E$ at low light intensities}

To determine the effect of different light intensities on the observed diurnal variability in $I E$, we measured $I E$ at PAR of 100,200 and $300 \mu \mathrm{mol} \mathrm{m}^{-2} \mathrm{~s}^{-1}$ on successive days at a constant leaf temperature $\left(30^{\circ} \mathrm{C}\right)$. For each light treatment $I E_{\max }$ occurred 2-3 hours after illumination (Figure 5). Following $I E_{\max }$ there was a steady decline in $I E$ during the afternoon. This is in contrast to the square wave function previously assumed, in which $I E$ rapidly stabilises at a given value, irrespective of the time of day, as long as PAR and temperature remain constant. However, the magnitude of $I E_{\max }$ was PAR dependent, which is consistent with previous reports (Guenther et al., 1993; Lerdau and Gray, 2003). 


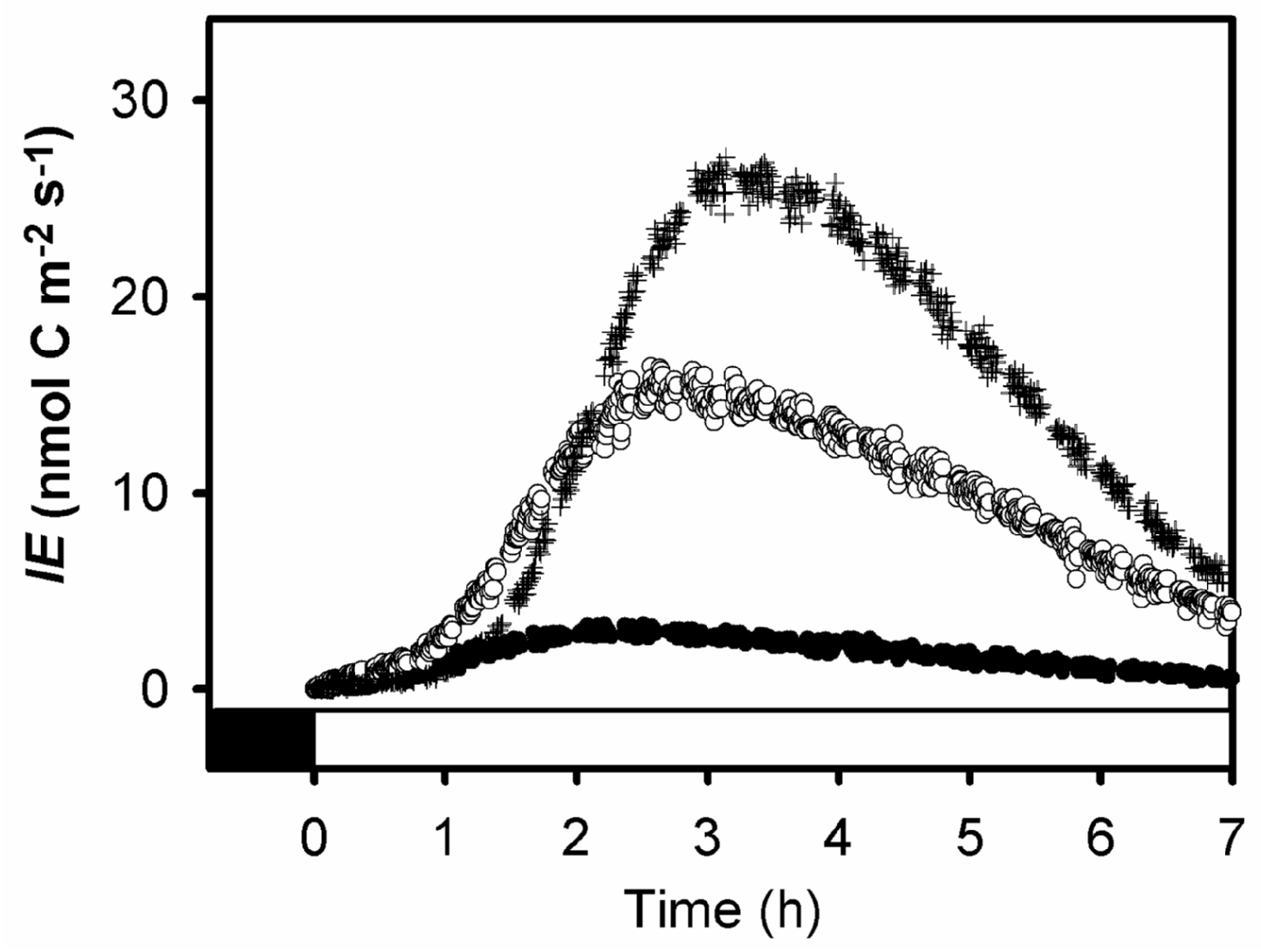

Figure 5. Diurnal variability in isoprene emission rates $(I E)$ at a constant leaf temperature of $30{ }^{\circ} \mathrm{C}$ and PAR of 100 (closed circles), 200 (open circles) and 300 (crosses) $\mu \mathrm{mol} \mathrm{m} \mathrm{m}^{-2} \mathrm{~s}^{-1}$ respectively. 


\section{$\underline{\text { Discussion }}$}

Despite considerable efforts to elucidate the physiological role of isoprene, its biological function still remains unclear. Several hypotheses have been proposed to explain its production by plants, including: a role as a mechanism to alleviate oxidative stress (Loreto et al., 2001; Affek and Yakir, 2002); a protectant of photosynthetic apparatus against thermal damage (Sharkey and Yeh, 2001); or as a mechanism to protect against excessive light (Penuelas and Munne-Bosch, 2005). Therefore, a circadian mechanism that allows plants to adjust to the diurnal variability of these different stresses and more efficiently protect the photosynthetic apparatus in high light and temperature environments would help to increase productivity and would be of evolutionary and ecological benefit. Circadian clocks represent an evolutionary adaptation allowing plants to optimise their biochemical and physiological activities in anticipation of the varying demands of the day/night cycle and to react to environmental signals (Millar and Kay, 1996). From an evolutionary perspective, this ability to synchronise with both external and internal environments may be critical to the plant's survival (Dodd et al., 2005).

The circadian rhythm in $I E$ can be measured across a broad range of light and temperature conditions, with the magnitude and amplitude dependent on these two parameters. Furthermore, by studying the transcriptional regulation of the central clockcomponent $C C A 1 / L H Y$, we have determined that the oil palm molecular clock maintains rhythmicity at a higher temperature $\left(38^{\circ} \mathrm{C}\right)$ than any previously recorded plant circadian rhythm. This suggests that a tropical species such as oil palm, which has evolved under temperatures that commonly reach a daytime maximum of $38{ }^{\circ} \mathrm{C}$ or more, has a clock that is pre-adapted to function at elevated temperatures. In contrast, circadian rhythms in 
many other plants, including species native to hot climates, have been reported to become arrhythmic at temperatures in the range $30-32{ }^{\circ} \mathrm{C}$ (Grams et al., 1995). Importantly, the period of the $E g C C A 1 / L H Y$ rhythm is shorter at $38{ }^{\circ} \mathrm{C}$ than it is at 25 ${ }^{\circ} \mathrm{C}$ and this correlates well with the shortening of the $I E$ period at $38{ }^{\circ} \mathrm{C}$. Together, these observations provide circumstantial evidence for a CCA1/LHY-TOC1-type molecular oscillator underlying isoprene emission rhythms in oil palm trees.

At present, it is unknown at which level(s) circadian regulation is applied to isoprene emission. Investigation of available promoter regions (1000-2000 bp) from poplar isoprene synthase genes (GenBank accession numbers AM084344 and AY341431 and sequences in the Populus trichocarpa genome, http://genome.jgipsf.org/Poptr1/Poptr1.home.html) reveals the presence of multiple copies of circadianassociated cis elements. These include: the binding site for CCA1 (AAa/cAATCT), which is conserved in light-harvesting complex $(L h c)$ gene promoters (Wang and Tobin, 1998) and is found in a number of circadian-regulated gene promoters (reviewed in (McClung, 2000; Nozue and Maloof, 2006); the core conserved sequence (CANNNNATC) of a region required for circadian regulation of the tomato $L h c$ genes (Piechulla et al., 1998); and the 'evening element' (AAATATCT), which was identified by in silico analyses of circadian-regulated gene promoters (Harmer et al., 2000). These elements are all closely related and may in fact represent the same conserved sequence. Their presence in the isoprene synthase gene promoters suggests that expression of isoprene synthase genes may be controlled in a circadian fashion at the transcriptional level. (Arimura et al., 2004) showed significant variability in isoprene synthase transcript levels between day and night in poplar leaves; this is consistent with the possibility that transcript abundance is under circadian control. Post-transcriptional 
regulation of circadian rhythms is also known to occur at several levels (reviewed in (Somers, 1999; Nozue and Maloof, 2006).

Circadian regulation may also be imposed on genes upstream in the MEP pathway for isoprene synthesis, resulting in circadian fluctuation of $I E$. It has been suggested that isoprene emissions may act as a biological "safety valve" for excess chloroplastic energy and carbon (Rosenstiel et al., 2004). Competition for phosphoenylpyruvate (PEP) between cytosolic and chloroplastic processes may result in changes in isoprene emission by preferentially diverting PEP away from the chloroplast (and hence isoprene synthesis) via the anapleurotic pathway for nitrate assimilation. It has long been known that nitrate assimilation is itself under circadian control at the level of nitrate reductase. As a result, when nitrate levels begin to increase during the afternoon to a late evening/early morning maximum (Yang and Midmore, 2005), isoprene emissions may decrease due to increased cytosolic competition for PEP. It is also known that several other components of the PEP metabolic pathway are under circadian control at levels of transcript abundance and protein activity (Hartwell et al., 1999; Streatfield et al., 1999; Sullivan et al., 2004; Hartwell, 2005), though circadian regulation of all of these components does not occur in all species. Clearly, the circadian control of PEP metabolism and chloroplast-cytosol partitioning, and its relation to the circadian rhythms of isoprene emissions reported here, merit further detailed investigation in a species such as oil palm. We are currently investigating this and other molecular levels at which circadian control may be imposed on $I E$.

Several attempts have been made to scale up isoprene emissions to produce regional and global scale emission inventories (Guenther et al., 1995; Simpson et al., 1999; Stewart et al., 2003). There are substantial uncertainties in these estimates already, and our discovery of strong circadian control of isoprene emissions is an additional complication that now must be taken into consideration when modelling 
isoprene fluxes from the biosphere to the atmosphere. While it is not known how widespread circadian regulation of isoprene emissions is, it is possible that other plant species as well as oil palm, especially in the tropics, exhibit this characteristic.

\section{$\underline{\text { Experimental procedures }}$}

\section{Field measurements of $I E_{1000 / 30}$}

Isoprene emission rates $\left(I E_{1000 / 30}\right)$ were measured from three frondlets of the same frond of a 5 year old oil palm tree growing in an oil palm plantation (Sabah, Malaysia, February 2004). Samples were collected using a leaf cuvette system (LCpro; ADC Biosciences, Hoddesdon, UK) which controlled PAR and leaf temperature (1000 $\left.\mu \mathrm{mol} \mathrm{m} \mathrm{s}^{-1} ; 30{ }^{\circ} \mathrm{C}\right)$. Inflow air $\left(350 \mathrm{ml} \mathrm{min}^{-1}\right)$ was filtered through charcoal to remove ozone and other ambient trace gases. Gas samples from the cuvette were taken into Perkin Elmer stainless steel sample tubes (89 mm x $6 \mathrm{~mm}$ O.D) at a rate of $100 \mathrm{ml} \mathrm{min}^{-1}$ for $15 \mathrm{~min}$. The sample tubes contained $100 \mathrm{mg}$ Carbotrap to trap isoprene. After sampling, tubes were sealed with 1/4" Swagelock caps and PTFE ferrules. Previous work has shown that samples can be stored for up to 8 weeks at $4{ }^{\circ} \mathrm{C}$ without significant loss of compound, provided samples are collected from an ozone-free cuvette system (Owen et al., 1997). Isoprene analysis was carried out by thermal desorption/capillary gas chromatography with mass selective detection (Possell et al., 2005).

\section{Plant material and growth conditions}

Three oil palm (Elaies guineenensis J. Gaertn.) trees were grown from seed for two years in Levingtons M3 compost (Fisons PLC, Ipswich, UK) in 10 litre containers under $12 \mathrm{~h}$ light $\left(250 \mathrm{umol} \mathrm{m} \mathrm{m}^{-2} \mathrm{~s}^{-1}\right) / 12 \mathrm{~h}$ dark with the tree illuminated between the 
hours of 06:00 and 18:00 at ambient temperatures of $30^{\circ} \mathrm{C}$ day and $20^{\circ} \mathrm{C}$ night. These conditions reflect typical under-storey conditions in a tropical plantation.

\section{Laboratory measurements of isoprene, $\mathrm{CO}_{2}$ assimilation and stomatal conductance}

Isoprene emission rates were measured using two systems. First we used a controlled environment broadleaf cuvette (PP-Systems, Hitchin, U.K.), modified for isoprene analysis, which allowed real time measurement of isoprene emission rates with simultaneous measurement of plant physiology (carbon assimilation rate and stomatal conductance) from a $2.5 \mathrm{~cm}^{2}$ section of frondlet held at precise conditions of $\mathrm{T}$ and PAR. Secondly a custom built chamber for whole-frond measurements, containing $\sim 1200 \mathrm{~cm}^{2}$ of frond was used. The latter system allowed real time measurements of isoprene emission rates but not of physiology.

Leaf physiological responses for the cuvette system were obtained using a CIRAS-1 differential $\mathrm{CO}_{2} / \mathrm{H}_{2} \mathrm{O}$ infrared gas analyser (PP-Systems, Hitchin, U.K.) to control humidity, $\mathrm{CO}_{2}$ concentration, leaf temperature, PAR and air flow rate through the cuvette. Water vapour concentration and $\mathrm{CO}_{2}$ concentration were measured with a precision of 0.7 mbar and $0.2 \mu 11^{-1}$ respectively. PAR was measured using a filtered silicon detector with a response range of 400-700 $\mathrm{nm}$ with a controllable flux precision of $\pm 10 \mu \mathrm{mol} \mathrm{m} \mathrm{m}^{-2}$. Inlet $\mathrm{CO}_{2}$ concentration was maintained at $360 \mu 1 \mathrm{l}^{-1}$. Leaf temperature was measured with an infrared radiation sensor. The air flow rate through the cuvette was $350 \mathrm{ml} \mathrm{min}^{-1}$, giving a residence time of $\sim 1$ second.

For whole frond branch measurements, excised palm fronds were cut under water. The cut end of the frond was kept underwater and the whole frond placed in the chamber. Illumination was from cold fluorescent lighting tubes $\left(120 \mu \mathrm{mol} \mathrm{m} \mathrm{s}^{-2}\right)$. Leaf temperature was controlled using thermocouples connected to a heat mat via a 
temperature controller (PXZ 4; Fuji Electric (UK Ltd), London), giving a frond surface temperature of $25^{\circ} \mathrm{C}$ or $38^{\circ} \mathrm{C}\left( \pm 0.3{ }^{\circ} \mathrm{C}\right)$. Air temperature, relative humidity and PAR were measured simultaneously (RHT2nl and QS2 sensors; Delta-T Devices Ltd., Cambridge, UK). All environmental parameters were recorded every 5 minutes using a DL2e data logger (Delta-T Devices Ltd., Cambridge, UK). The air flow rate through the chamber was $3 \mathrm{~L} \mathrm{~min}^{-1}$, giving a residence time of $\sim 10 \mathrm{~min}$. The rate at which air was introduced into both cuvette and frond chamber was mass flow controlled and scrubbed of isoprene using activated charcoal.

Air from both leaf and frond chambers was introduced at a rate of $100 \mathrm{ml} \mathrm{min}$

${ }^{1}$ into a proton transfer reaction mass spectrometer (PTR-MS) (Ionicon GmbH, Innsbruck, Austria) for isoprene analysis. The PTR-MS was calibrated by dilution of a $700 \mathrm{ppb}$ isoprene gas standard (Linde UK Ltd. Aberdeen, Scotland) and operated with an $E / N$ ratio of $125 \mathrm{Td}$ (Hayward et al., 2002). Air samples from the cuvette were also collected on $6 \mathrm{~mm}$ OD stainless steel sample tubes containing absorbent resin (Carbotrap; Supelco, Bellefonte, PA) for isoprene identification using gas chromatography-mass spectrometry (Turbomatrix Gold; Perkin Elmer, Boston. USA.). The analytical procedure followed that of Possell et al. (2005).

\section{Identification of an oil palm $C C A 1 / L H Y$ orthologue}

We identified an oil palm CCA1/LHY EST in the GenBank EST database using the TBLASTN search algorithm. The translated EgCCA1/LHY EST (GenBank accession number CN600590) aligns with the Arabidopsis AtLHY protein from amino acid residue 235 to residue 350 and shares $35.4 \%$ identity with AtLHY across this region. Phylogenetic tree analysis confirmed that this EST was a good orthologue of 
$A t C C A 1 / L H Y$ and was most closely related to $A t L H Y$ (data not shown). We also identified an oil palm EST that is an orthologue of the Arabidopsis polyubiquitin 10 gene $(U B Q 10)$, which we used as a loading control in our real-time PCR expression analysis. This gene is routinely used in Arabidopsis as a loading control for real-time PCR analysis (Gould et al., 2006). The EgUBQ10 EST corresponds to GenBank accession number CN600235. Gene specific primers for real-time PCR of EgCCA1/LHY and EgUBQ10 were designed as follows: EgCCA1/LHYF 5'ACCCTTTACCCAATTCCACA-3', EgCCA1/LHYR 5'CAGGCTTGGATAAGGGTTCA-3', EgUBQ10F 5'GACAACGTCAAGGCCAAGAT-3' and EgUBQ10R 5'CTCGAGGGTGATCGTCTTTC-3’.

\section{RNA isolation}

Frondlet samples were collected and frozen in liquid nitrogen every six hours from an excised oil palm frond maintained in constant light $\left(120 \mu \mathrm{mol} \mathrm{m} \mathrm{m}^{-2} \mathrm{~s}^{-1}\right)$ and at a constant temperature of either $25^{\circ} \mathrm{C}$ or $38^{\circ} \mathrm{C}$ in the branch chamber. Frozen frondlet samples were ground in liquid nitrogen using a mortar and pestle, and total RNA was isolated using an acetyl-trimethyl ammonium bromide-based RNA extraction procedure (Hartwell et al., 1996). The quantity and purity of the RNA were determined spectrophotometrically as described (Sambrook, 1989).

\section{Reverse transcription and real-time PCR}

Total RNA samples $(1 \mu \mathrm{g})$ were reverse-transcribed using random hexamers and the QuantiTect ${ }^{\mathrm{TM}}$ Reverse Transcription kit with integrated genomic gDNA Wipeout buffer (Qiagen, Crawley, UK) according to the manufacturer's instructions. 
$E g C C A 1 / L H Y$ transcript abundance was measured in each sample relative to $E g U B Q 10$ using real-time PCR in a Rotor-Gene $3000^{\mathrm{TM}}$ (Corbett Research Ltd, Cambridge UK). Each reaction contained $2 \mu 1$ of cDNA and $6 \mu$ l of QuantiTect ${ }^{\mathrm{TM}}$ SYBR Green PCR mix (Qiagen, Crawley, UK) together with the gene specific primers for $E g C C A 1 / L H Y$ or $E g U B Q 10$. The efficiency value of amplification for each set of primers was determined by measuring the abundance of transcripts from a cDNA dilution series. Efficiency values were computed for each primer set using REST (Pfaffl et al., 2002). Each RNA sample was assayed in triplicate. The $E g C C A 1 / L H Y$ transcript abundance levels were normalised to $E g U B Q 10$ using Q-gene software (http://www.biotechniques.com/softlib/qgene.html) (Muller et al., 2002).

Acknowledgements: This work was funded by the Natural Environment Research Council. Additional support was provided by the European Science Foundation "VOCBAS" programme and the European Commission's Marie Curie Research and Training Network "ISONET".

\section{References}

Affek, H.P. and Yakir, D. (2002) Protection by isoprene against singlet oxygen in leaves. Plant Physiol., 129, 269-277.

Alabadi, D., Oyama, T., Yanovsky, M.J., Harmon, F.G., Mas, P. and Kay, S.A. (2001) Reciprocal regulation between TOC1 and LHY/CCA1 within the Arabidopsis circadian clock. Science, 293, 880-883. 
Arimura, G., Huber, D.P.W. and Bohlmann, J. (2004) Forest tent caterpillars (Malacosoma disstria) induce local and systemic diurnal emissions of terpenoid volatiles in hybrid poplar (Populus trichocarpa x deltoides): cDNA cloning, functional characterization, and patterns of gene expression of (-)-germacrene D synthase, PtdTPS1. Plant J., 37, 603-616.

Boxall, S.E., Foster, J.M., Bohnert, H.J., Cushman, J.C., Nimmo, H.G. and Hartwell, J. (2005) Conservation and divergence of circadian clock operation in a stress-inducible crassulacean acid metabolism species reveals clock compensation against stress. Plant Physiol., 137, 969-982.

Claeys, M., Graham, B., Vas, G., Wang, W., Vermeylen, R., Pashynska, V., Cafmeyer, J., Guyon, P., Andreae, M.O., Artaxo, P. and Maenhaut, W. (2004) Formation of secondary organic aerosols through photooxidation of isoprene. Science, 303, 1173-1176.

Dodd, A.N., Salathia, N., Hall, A., Kevei, E., Toth, R., Nagy, F., Hibberd, J.M., Millar, A.J. and Webb, A.A.R. (2005) Plant circadian clocks increase photosynthesis, growth, survival, and competitive advantage. Science, 309, 630-633.

Fall, R. (1999) Biogenic emissions of volatile organic emissions from higher plants. In Reactive hydrocarbons in the atmosphere (Hewitt C.N., ed). Academic Press, pp. 43-97. Funk, J.L., Jones, C.G. and Lerdau, M.T. (1999) Defoliation effects on isoprene emission from Populus deltoides. Oecologia, 118, 333-339.

Funk, J.L., Jones, C.G., Baker, C.J., Fuller, H.M., Giardina, C.P. and Lerdau, M.T. (2003) Diurnal variation in the basal emission rate of isoprene. Ecol. Appl., 13, 269-278. 
Geron, C., Guenther, A., Sharkey, T. and Arnts, R.R. (2000) Temporal variability in basal isoprene emission factor. Tree Physiol., 20, 799-805.

Gould, P.D., Locke, J.C.W., Larue, C., Southern, M.M., Davis, S.J., Hanano, S., Putterill, J., Millar, A.J. and Hall, A.J.W. (2006) The molecular basis of temperature compensation in the Arabidopsis circadian clock. Plant Cell. (in press)

Grams, T.E.E., Kluge, M. and Luttge, U. (1995) High temperature-adapted plants of Kalanchoe daigremontiana show changes in temperature dependence of the endogenous CAM rhythm. J. Exp. Bot., 46, 1927-1929.

Guenther, A., Hewitt, C.N., Erickson, D., Fall, R., Geron, C., Graedel, T., Harley, P., Klinger, L., Lerdau, M., McKay, W.A., Pierce, T., Scholes, B., Steinbrecher, R., Tallamraju, R., Taylor, J. and Zimmerman, P. (1995) A Global-Model Of Natural Volatile Organic-Compound Emissions. J. Geophys. Res-Atmos., 100, 8873-8892. Guenther, A.B., Zimmerman, P.R., Harley, P.C., Monson, R.K. and Fall, R. (1993) Isoprene and Monoterpene Emission Rate Variability - Model Evaluations and Sensitivity Analyses. J. Geophys. Res-Atmos., 98, 12609-12617.

Harley, P.C., Litvak, M.E., Sharkey, T.D. and Monson, R.K. (1994) Isoprene emission from velvet bean leaves - interactions among nitrogen availability, growth photon flux density, and leaf development. Plant Physiol., 105, 279-285.

Harley, P.C., Monson, R.K. and Lerdau, M.T. (1999) Ecological and evolutionary aspects of isoprene emission from plants. Oecologia, 118, 109-123.

Harmer, S.L., Hogenesch, L.B., Straume, M., Chang, H.S., Han, B., Zhu, T., Wang, X., Kreps, J.A. and Kay, S.A. (2000) Orchestrated transcription of key pathways in Arabidopsis by the circadian clock. Science, 290, 2110-2113. 
Hartwell, J., Smith, L.H., Wilkins, M.B., Jenkins, G.I. and Nimmo, H.G. (1996)

Higher plant phosphoenolpyruvate carboxylase kinase is regulated at the level of translatable mRNA in response to light or a circadian rhythm. Plant J., 10, 1071-1078.

Hartwell, J., Gill, A., Nimmo, G.A., Wilkins, M.B., Jenkins, G.L. and Nimmo, H.G. (1999) Phosphoenolpyruvate carboxylase kinase is a novel protein kinase regulated at the level of expression. Plant J., 20, 333-342.

Hartwell, J., Nimmo, G.A., Wilkins, M.B., Jenkins, G.I. and Nimmo, H.G. (2002)

Probing the circadian control of phosphoenolpyruvate carboxylase kinase expression in Kalanchoe fedtschenkoi. Funct. Plant Biol., 29, 663-668.

Hartwell, J. (2005) The circadian clock in CAM plants. In Endogenous Plant Rhythms (Hall, A. and McWatters, H.G., eds.). Blackwell, Oxford UK, pp. 211-236.

Hayward, S., Hewitt, C.N., Sartin, J.H. and Owen, S.M. (2002) Performance characteristics and applications of a proton transfer reaction-mass spectrometer for measuring volatile organic compounds in ambient air. Env. Sci. Technol., 36, 15541560.

Izawa, T., Takahashi, Y. and Yano, M. (2003) Comparative biology comes into bloom: genomic and genetic comparison of flowering pathways in rice and Arabidopsis. Curr. Opin. Plant Biol., 6, 113-120.

Kaldis, A.D., Kousidis, P., Kesanopoulos, K. and Prombona, A. (2003) Light and circadian regulation in the expression of LHY and Lhcb genes in Phaseolus vulgaris. Plant Mol. Biol., 52, 981-997.

Karl, T., Fall, R., Rosenstiel, T.N., Prazeller, P., Larsen, B., Seufert, G. and Lindinger, W. (2002) On-line analysis of the (CO2)-C-13 labeling of leaf isoprene suggests multiple subcellular origins of isoprene precursors. Planta, 215, 894-905. 
Kuzma, J. and Fall, R. (1993) Leaf Isoprene Emission Rate Is Dependent on Leaf Development and the Level of Isoprene Synthase. Plant Physiol., 101, 435-440.

Lerdau, M. and Gray, D. (2003) Ecology and evolution of light-dependent and lightindependent phytogenic volatile organic carbon. New Phytol., 157, 199-211.

Loreto, F., Mannozzi, M., Maris, C., Nascetti, P., Ferranti, F. and Pasqualini, S. (2001) Ozone quenching properties of isoprene and its antioxidant role in leaves. Plant Physiol., 126, 993-1000.

McClung, C.R. (2000) Circadian rhythms in plants: a millennial view. Physiol. Plantarum, 109, 359-371.

McClung, C.R. (2001) Circadian rhythms in plants. Annu. Rev. Plant Physiol. Plant Mol. Biol., 52, 139-162.

Millar, A.J. and Kay, S.A. (1996) Integration of circadian and phototransduction pathways in the network controlling CAB gene transcription in Arabidopsis. Proc. Nat. Acad. Sci., 93, 15491-15496.

Muller, P.Y., Janovjak, H., Miserez, A.R. and Dobbie, Z. (2002) Processing of gene expression data generated by quantitative real-time RT-PCR. Biotechniques, 32, 13721379.

Niinemets, U. and Reichstein, M. (2003a) Controls on the emission of plant volatiles through stomata: A sensitivity analysis. J. Geophy. Res-Atmos., 108: D7, 4211, doi:10.1029/2002JD002626

Niinemets, U. and Reichstein, M. (2003b) Controls on the emission of plant volatiles through stomata: Differential sensitivity of emission rates to stomatal closure explained. J. Geophys. Res-Atmos., 108: D7, 4208, doi:10.1029/2002JD002620 
Nozue, K. and Maloof, J.N. (2006) Diurnal regulation of plant growth. Plant Cell Environ., 29, 396-408.

Owen, S., Boissard, C., Street, R.A., Duckham, S.C., Csiky, O. and Hewitt, C.N. (1997) Screening of 18 Mediterranean plant species for volatile organic compound emissions [Full text delivery]. Atmos. Environ., 31, 101-117.

Pegoraro, E., Rey, A., Greenberg, J., Harley, P., Grace, J., Malhi, Y. and Guenther, A. (2004) Effect of drought on isoprene emission rates from leaves of Quercus virginiana Mill. Atmos. Environ., 38, 6149-6156.

Penuelas, J. and Munne-Bosch, S. (2005) Isoprenoids: an evolutionary pool for photoprotection. Trends Plant Sci., 10, 166-169.

Pfaffl, M.W., Horgan, G.W. and Dempfle, L. (2002) Relative expression software tool (REST (c)) for group-wise comparison and statistical analysis of relative expression results in real-time PCR. Nucleic Acids Res., 30, No.9 e36

Piechulla, B., Merforth, N. and Rudolph, B. (1998) Identification of tomato Lhc promoter regions necessary for circadian expression. Plant Mol. Biol., 38, 655-662. Pierce, T., Geron, C., Bender, L., Dennis, R., Tonnesen, G. and Guenther, A. (1998) Influence of increased isoprene emissions on regional ozone modeling. $J$. Geophys. Res-Atmos., 103, 25611-25629.

Poisson, N., Kanakidou, M. and Crutzen, P.J. (2000) Impact of non-methane hydrocarbons on tropospheric chemistry and the oxidizing power of the global troposphere: 3- dimensional modelling results. J. Atmos. Chem., 36, 157-230.

Possell, M., Heath, J., Nicholas Hewitt, C., Ayres, E. and Kerstiens, G. (2004) Interactive effects of elevated $\mathrm{CO} 2$ and soil fertility on isoprene emissions from Quercus robur. Global Change Biol., 10, 1835-1843. 
Possell, M., Hewitt, C.N. and Beerling, D.J. (2005) The effects of glacial atmospheric $\mathrm{CO} 2$ concentrations and climate on isoprene emissions by vascular plants. Global Change Biol., 11, 60-69.

Ramos, A., Perez-Solis, E., Ibanez, C., Casado, R., Collada, C., Gomez, L., Aragoncillo, C. and Allona, I. (2005) Winter disruption of the circadian clock in chestnut. Proc. Nat. Acad. Sci., 102, 7037-7042.

Rosenstiel, T.N., Ebbets, A.L., Khatri, W.C., Fall, R. and Monson, R.K. (2004) Induction of poplar leaf nitrate reductase: A test of extrachloroplastic control of isoprene emission rate. Plant Biol., 6, 12-21.

Sambrook, J., Fritsch, E.F., Maniatis, T. (1989) Molecular cloning: A laboratory manual, 2nd edn. Cold Spring Harbor: Cold Spring Harbour Laboratory Press.

Schaffer, R., Ramsay, N., Samach, A., Corden, S., Putterill, J., Carre, I.A. and Coupland, G. (1998) The late elongated hypocotyl mutation of Arabidopsis disrupts circadian rhythms and the photoperiodic control of flowering. Cell, 93, 1219-1229. Shallcross, D.E. and Monks, P.S. (2000) New Directions: A role for isoprene in biosphere-climate- chemistry feedbacks. Atmos. Environ., 34, 1659-1660.

Sharkey, T.D., Singsaas, E.L., Lerdau, M.T. and Geron, C.D. (1999) Weather effects on isoprene emission capacity and applications in emissions algorithms. Ecol.ogical Appl., 9, 1132-1137.

Sharkey, T.D., Chen, X.Y. and Yeh, S. (2001) Isoprene increases thermotolerance of fosmidomycin-fed leaves. Plant Physiol., 125, 2001-2006.

Sharkey, T.D. and Yeh, S.S. (2001) Isoprene emission from plants. Annu. Rev. Plant Physiol. Plant Mol. Biol., 52, 407-436. 
Simpson, D., Winiwarter, W., Borjesson, G., Cinderby, S., Ferreiro, A., Guenther, A., Hewitt, C.N., Janson, R., Khalil, M.A.K., Owen, S., Pierce, T.E., Puxbaum, H., Shearer, M., Skiba, U., Steinbrecher, R., Tarrason, L. and Oquist, M.G. (1999) Inventorying emissions from nature in Europe. J. Geophys. Res.-Atmos., 104, 81138152.

Somers, D.E. (1999) The physiology and molecular bases of the plant circadian clock. Plant Physiol., 121, 9-19.

Stewart, H.E., Hewitt, C.N., Bunce, R.G.H., Steinbrecher, R., Smiatek, G. and Schoenemeyer, T. (2003) A highly spatially and temporally resolved inventory for biogenic isoprene and monoterpene emissions: Model description and application to Great Britain. J. Geophys. Res.-Atmos., 108: D20, 4644, doi:10.1029/2002JD002694 Streatfield, S.J., Weber, A., Kinsman, E.A., Hausler, R.E., Li, J.M., PostBeittenmiller, D., Kaiser, W.M., Pyke, K.A., Flugge, U.I. and Chory, J. (1999) The phosphoenolpyruvate/phosphate translocator is required for phenolic metabolism, palisade cell development, and plastid-dependent nuclear gene expression. Plant Cell, 11, 1609-1621.

Sullivan, S., Jenkins, G.I. and Nimmo, H.G. (2004) Roots, cycles and leaves. Expression of the phosphoenolpyruvate carboxylase kinase gene family in soybean. Plant Physiol., 135, 2078-2087.

Wang, Z.Y. and Tobin, E.M. (1998) Constitutive expression of the CIRCADIAN CLOCK ASSOCIATED 1 (CCA1) gene disrupts circadian rhythms and suppresses its own expression. Cell, 93, 1207-1217. 
Wolfertz, M., Sharkey, T.D., Boland, W., Kuhnemann, F., Yeh, S.S. and Weise,

S.E. (2003) Biochemical regulation of isoprene emission. Plant Cell Environ., 26, $1357-$ 1364.

Yang, Z.J. and Midmore, D.J. (2005) A model for the circadian oscillations in expression and activity of nitrate reductase in higher plants. Ann. Botany, 96, 10191026. 